\title{
The art of failure in translating a Navajo poem
}

L'art de l'échec dans la traduction d'un poème navajo

El arte de fallar traduciendo un poema navajo

Anthony K. Webster

\section{CpenEdition}

\section{Journals}

Electronic version

URL: https://journals.openedition.org/jsa/14602

DOI: 10.4000/jsa.14602

ISSN: 1957-7842

Publisher

Société des américanistes

Printed version

Date of publication: 31 October 2016

Number of pages: 9-41

ISSN: 0037-9174

\section{Electronic reference}

Anthony K. Webster, "The art of failure in translating a Navajo poem", Journal de la Société des américanistes [Online], 102-1 | 2016, Online since 08 December 2016, connection on 03 September 2022. URL: http://journals.openedition.org/jsa/14602 ; DOl: https://doi.org/10.4000/jsa. 14602

All rights reserved 


\title{
The art of failure in translating a Navajo poem
}

\author{
Anthony K. WeBSTER *
}

This article engages John Ciardi's famous dictum that translation is « the art of failure » by engaging in a thick translation and a creative transposition of a short poem in Navajo by Rex Lee Jim. I begin with reflections on recent discussions in anthropology on translation and voice - both of which will be relevant to the argument advanced in my discussion of Jim's poem. I then work through a transcript of an interview with Jim about his poetry. I then engage in a creative transposition, or more precisely a failure, of the poem, and engage in a bit of exegesis and philology about the poem. The goal is to bring a concern with voice into dialogue with a concern with theorizations of translation. Mostly, though, this article is a contemplative exercise in the art of failure and in attending to the value of such an intellectual and aesthetic endeavor. [Key words: Navajo, poetry, translation, sound, voice, failure.]

L'art de l'échec dans la traduction d'un poème navajo. Cet article s'attaque à la fameuse maxime de John Ciardi, qui affirme que la traduction est « l'art de l'échec », en entreprenant une "traduction étoffée » (thick translation) et une transposition créative d'un court poème en navajo de Rex Lee Jim. Je commence en commentant des débats récents en anthropologie au sujet de la traduction et de la voix - qui seront tous les deux pertinents pour l'argumentation que je développe dans ma discussion du poème de Jim. Ensuite, j'examine morceau par morceau la transcription d'une interview de Jim à propos de sa poésie. Puis j'entreprends une transposition creative du poème, qui est plus précisément un échec, et je me livre à un peu d'exégèse et philologie du poème. Mon but est que l'attention apportée à la voix dialogue avec un intérêt pour les théories de la traduction. Cependant, cet article est surtout un exercice méditatif sur l'art de l'échec et sur la valeur que l'on peut accorder à une telle entreprise intellectuelle et esthétique. [Mots-clés : Navajo, poésie, traduction, son, voix, échec.]

El arte de fallar traduciendo un poema navajo. Este artículo analiza el famoso dictum de John Ciardi sobre la traducción como « el arte de fallar» a través de la

* Department of Anthropology, University of Texas at Austin, 2201 Speedway Stop C3200, Austin TX 78712 [awebster@utexas.edu]. 
traducción densa y la transposición creativa de un poema corto en Navajo compuesto por Rex Lee Jim. Comienzo reflexionando sobre discusiones recientes en la antropología de la traducción y la voz - ambas relevantes para el argumento que avanzo en mi discusión sobre la poesía de Jim. Luego analizo la transcripción de una entrevista con Jim acerca de su poesía. Luego propongo una transposición creativa, o más precisamente una falla, del poema y hago un poco de exésgesis y filología acerca del poema. El objetivo es poner la preocupación acerca de la voz en diálogo con la teorización de la traducción. Más que nada, sin embargo, el articulo es un ejercicio contemplativo acerca del arte de fallar y un intento de valorar estos esfuerzos intelectuales y estéticos. [Palabras clave: navajo, poesía, traducción, sonido, voz, falla.]

The pun, or to use a more erudite, and perhaps more precise term - paronomasia, reigns over poetic art, and whether its rule is absolute or limited, poetry by definition is untranslatable.

Roman Jakobson (1959, p. 238)

\section{The art of failure}

John Ciardi (1961, p. 17), in a piece for the Saturday Review, famously (if often misattributed) called translation «the art of failure ». Ciardi was the poetry editor for the Saturday Review and had been engaged for fifteen years in an effort to translate Dante's Inferno. He argued, in the end, that the goal of the translator - and he is rightly uncomfortable with this term because it assumes an isomorphism, not just of denotation but of register (my term), of history (his term), and of «muscularity » (his term), between languages - is to create « the best possible failure » (Ciardi 1961, p. 17). While Ciardi would surely concur with Jakobson's (1959, p. 238) quote above, that it seems clear that " poetry by definition is untranslatable », there is, at least, an art in the failure of translation. There is value, intellectual and aesthetic, in our failures of translation. Jakobson (1959, p. 238), for his part, would call such failures of translating poetry, from one language to another, " creative transpositions » and specifically this would be an example of « interlingual transposition ».

Like Ciardi, I have spent more than fifteen years attempting to translate the poetry of Navajo poet Rex Lee Jim (Webster 2004, 2006, 2009, 2015a, 2015b, 2017; Mitchell and Webster 2011). Jim's poetry, as I have described elsewhere, is replete with puns (see, for example, Webster 2013, 2015a, 2017). The very sounds of the poem, its physicality, have proven impossible for me to translate (see Webster 2015c). The muscularity of producing the poems, the feel of saying the poem, has also proven impossible to translate (see Mitchell and Webster 2011; Webster 2015c). I do not consider these failings to be trivial. " Sound », as Jim once explained to me, « is very important ». As Rosmarie 
Waldrop (2009, p. 60) has noted, in a perceptive piece on the perils of translating the sound in and of poetry, « it is impossible to translate the sound in poetry because the union of sound/sense will not be the same in any other language $»$. This is true as far as it goes, but - and here is what I find so useful in Ciardi's piece - there is also the muscularity, the physicality of producing (speaking) the poem. One thing that gets lost, as it were, in translation is the sounds of the poem. Another thing, equally important, is the feel of saying the poem, the physicality of expression ${ }^{1}$.

This article is an attempt at thick translation and a creative transposition of a short poem in Navajo by Rex Lee Jim. I will, however, begin with some reflections on recent discussions in anthropology on translation and voice - both of which will be relevant to the argument advanced in my discussion of Jim's poem. The article takes a discourse-centered approach (Sherzer 1987, 1994), in that the core of the article will be the working through of a stretch of discourse - an interview between myself and Jim. I will supplement the transcript with commentary that I hope will make clearer some of what Jim tells me. I follow that by offering a creative transposition, or more precisely a failure, of the poem, and engage in a bit of exegesis and philology about the poem. The goal is to bring a concern with voice into dialogue with a concern with theorizations of translation. Mostly, though, this article is a contemplative exercise in the art of failure and in attending to the value of such an intellectual and aesthetic endeavor.

\section{Translating the phonosonic nexus}

Of late, in anthropology and ethnomusicology, there has been much concern with the muscularity and physicality of speaking (or singing) and in the materiality of such sounded phenomenon (see Weidman 2006, 2015; Feld et al. 2004; Harkness 2013; Jacobsen 2014; Kunreuther 2014). David Samuels and Thomas Porcello (2015, p. 95) describe it as « the sonic materiality of speech » and argue for the importance of attending to " the material embodiment of language as socially circulating sound » (Samuels and Porcello 2015, p. 96). Part of this concern has developed out of the twin and twined senses of « voice » (Weidman 2014, 2015; Kunreuther 2014). On the one hand, voice is understood as a metaphor for human agency (« finding one's voice », « voice of the people », etc.). On the other hand, « the materiality of voice has to do with

1. The physicality of expression has long been a concern in the literature concerning ideophony and expressives (see Diffloth 1976; Nuckolls 1999; Mitchell and Webster 2011; Webster 2015c). Similar arguments on the twining of sound and sense have been made by Bolinger (1940, 1949, 1950), and Hymes (1960) for English; Durbin (1973) for Mayan; and Gell (1979) for Umeda. 
sound itself as well as with the bodily processes of producing and attending to voices » (Weidman 2015, p. 235). Nickolas Harkness (2013, p. 12) calls this the «phonosonic nexus ». By this he means that « the voice [is] an ongoing intersection between the phonic production, shaping, and organization of sound, on the one hand, and the sonic uptake and categorization of sound in the world, on the other » (Harkness 2013, p. 12). Paul Friedrich (1986, 1998), in his richly evocative work, described this materiality and physicality of language, of voice, as the music of language(s).

Another developing strand in linguistic anthropology has been a renewed theorizing about translation as social practice (Severi and Hanks 2015; Gal 2015; Silverstein 2003). Here translation is understood not just as between languages, but also « cross-cultural translation » as one of the « perennial challenges facing anthropologists » (Hanks 2015, p. 21; see also Keesing 1989). The work in Carlo Severi and William Hanks (2015) also calls attention to concerns with intralingual and intracultural translation. Intralingual translation has been an on-going concern in discussions of esoteric and ritual language (see, for example, Bahr 1983). Much of this work pushes us to think more critically not just about denotation but also indexicalities of languages as embedded in and constitutive of social practices (Silverstein 2003; Gal 2015). As Hanks and Severi $(2015$, p. 2) note, « translation is both how we constitute our objects and how we make claims about them ». While there are risks, as John Leavitt (2015, p. 261) suggests, in treating « translation » of cultures and languages as equivalent, there is also value in attending to the semiotics of such acts, such processes, of « translation ».

If these arguments have a failing though, it is a general lack of interest in the sounds of languages and in iconicity, in what Samuels (2001, p. 289) has termed « phonological iconicity » (roughly sounds resembling sounds in language) and, in particular, to recall Jakobson's discussion of poetry above, punning. While Hanks and Severi (2015, p. 10), for example, take up Stephen Levinson's (2003, p. 28) critique of « simple nativism » and merely finding the right «phonetic clothing » for « preexisting mental representation[s] », they do not take that « phonetic clothing » seriously. This becomes clear in the following claim by Hanks and Severi (2015, p. 16):

Every language and every culture are not only different from each other; they are also translatable into each other. No untranslatable language, or culture, has ever existed. This quality of being translatable is inherent in all forms of human communication, as well as in the generation of cultural differences.

What are we to make of this claim that, « all forms of human communication » are translatable? Is poetry, certainly a form of human communication, translatable? Jakobson, as we saw in our opening epigraph, argues to the contrary that it is untranslatable. Why is poetry, according to Jakobson $(1959,1960)$, 
untranslatable? Partly this is definitional in nature. According to Jakobson's (1960, p. 356) famous formulation of the poetic function it is a «focus on the message for its own sake »; it is the very form of the message that matters here and no two languages share the same sound and sense configuration. As Jakobson (1960, p. 372) notes, « in poetry, any conspicuous similarity in sound is evaluated in respect to similarity and/or dissimilarity in meaning ». Form is content in poetry. And here punning becomes paramount: « the supremacy of poetic function over referential function does not obliterate the reference but makes it ambiguous » (Jakobson 1960, p. 371) ${ }^{2}$. Resolving the ambiguity of poetry is not to translate poetry, but to convert it into not poetry (into exegesis, perhaps, or thick translation) ${ }^{3}$. The simultaneity of a pun, its bivalency (its very pun-ness!), is lost when the pun is resolved in translation (see Woolard 1998). Sonic equivalencies (the twining of sound and sense) are lost across languages. Lost in such discussions of translation is any attention, then, to the phonosonic nexus, the music, of language. To put it succinctly, many of these discussions of translation are predicated on a language ideology (or, perhaps, an entailed

2. The alert reader will note that Jakobson (1960) does not confine the poetic function to only poetry, but rather that it is a part - to varying degrees - of all language use. If poetry is untranslatable because of the play of the poetic function, and if all language in use partakes to some degree of the poetic function, then there are always limits on our ability to translate across languages or within languages (see also Friedrich 1979, 1986). Edward Sapir (1921, p. 222) argues that, « every language has its distinctive peculiarities, the innate formal limitations - and possibilities - of one literature are never quite the same as those of another $»$. Yet he also notes that, " nevertheless, literature does get itself translated, sometimes with astonishing adequacy " (Sapir 1921, p. 222) and goes on to argue, " literature moves in language as a medium, but that medium comprises two layers, the latent content of language - our intuitive record of experience - and the particular conformation of a given language - the specific how of our record of experience. Literature that draws its sustenance mainly - never entirely - from the lower level, say a play of Shakespeare's, is translatable without too great a loss of character » (Sapir 1921, p. 223). I wonder, however, given the abundance of puns in Shakespeare how much character is lost in " translation ». For example, to take a famous example, the pun from Richard III (act 1, scene 1) between " son » and " sun » ( «made glorious summer by this son of York ») does not, obviously, work in Navajo: « sun » might be glossed into Navajo as either shá (which can pun with «for me ») or jóhonaa 'éi and «son » can be glossed - depending on the speaker - as either 'ayáázh « someone's son » (female speaking) or 'aye' " someone's son » (male speaking). In Navajo, kin terms are inalienable and hence require a possessive prefix (here the indefinite possessive ' $a$ « someone's »). For me, anyway, it's never been the plots of Shakespeare that have inspired (tragedies end in death, comedies in marriage) but the dexterity of language play in the plays.

3. The importance of ambiguity for Navajos has often been remarked upon. David McAllester (1980, p. 19) makes the following observation concerning the translation of song texts, «the point here is that in song texts as well as in ordinary conversation, the Navajos do not feel a great necessity to make all reference clear. In fact a certain ambiguity is preferred ». See also Peterson and Webster (2013) on how the Navajo language is sometimes described as both very precise and very ambiguous. 
semiotic ideology) that denies the materiality of languages (see Samuels 2004; Leavitt 2006, 2015; Bauman and Briggs 2003 for some of the relevant history).

Concurrent with this renewed concern in anthropology about translation, or at least as an interested party to the debates occurring about a re-theorized notion of translation, has been an ethnopoetically informed concern with the doing of translation (Sammons and Sherzer 2000; Woodbury 2007; Leavitt 2006, 2015; Nuckolls 2000; McDowell 2000; Kozak 2012). Here there has been concern with the craft, or art, of translation. Much of this concern has been rooted in a concern with ethnopoetics and verbal artistry. Kwame Appiah (1993), Anthony Woodbury (2007), and John Leavitt (2006) all call this « thick translation ». By « thick translation », Leavitt (2006, p. 79), for example, means a « combination of an anthropologist's attention to cultural context with a nearly or truly philological attention to the specifics of texts ». Leavitt $(2006,2015)$ is influenced by, among others, the work of Paul Friedrich $(1979,1986)$, the modern philology of Alton Becker (1995), and the anthropological philology qua ethnopoetics of Dell Hymes (1981, 2003). While Leavitt (2006, p. 104) argues that many anthropologists have been adept at exegesis, of contextualization and interpretation, he notes that, « what anthropologists still tend to neglect... is philology, the music and mechanics of the text itself in the original language ». Taking a cue from Hymes (1981), Leavitt (2015, p. 288) concludes his later piece on translation by noting, «As Dell Hymes (1981) called for anthropological philology, perhaps this would be philological anthropology. » This philological anthropology or thick translation (and I'll use the terms interchangeably), with its attention to the music of the text, the sounds of the text, should provoke consideration, as well, of discussions concerning voice. It seems to me that a concern with voice, or the phonosonic nexus, the muscularity and materiality of speaking, its very physicality, should be a part of discussions of thick translations and/or philological anthropology.

Perhaps, conceding to Jakobson (1959) that the best that can be done with regard poetry is a kind of « creative transposition », we might think of our work as both a thick translation and creative transposition. Though Jakobson (1959) is not entirely clear on this point, by « creative transposition », I take him to be suggesting the writing/creating of a poem in another language (or another register or another modality) that is inspired by a poem in a different language ${ }^{4}$.

4. Creative transposition might also, following an insightful piece by Oswald Werner (1994, p. 66), be called a "stimulus translation ». Werner (1994, p. 66) defines it thus: «Therefore, strictly speaking, stimulus translation of a text is not translation in the ordinary sense of the word. It is the creation of a new text stimulated by the source language original. » While Werner's notion of « stimulus translation » seems similar to what I take Jakobson (1959) to be describing with « creative transposition », I prefer Jakobson's term precisely because it eschews the problematic word «translation ». Ossy Werner gave me 


\section{« I am a poet »}

I met my first Navajo poet in March of 2000. We met in Window Rock, AZ at what was then the Navajo Nation Inn. I was there trying to figure out a dissertation project. He was there having lunch but graciously agreed to wait around for me so that we might meet and talk. The poet I met that day was Rex Lee Jim. At the time he was teaching at the recently renamed Diné College (formerly Navajo Community College). He had published three books of poetry at that time: two were entirely in Navajo (Jim 1989, 1995), the third in Navajo, Gaelic, and English (Jim 1998). Over the next several months I would interview him multiple times about his poetry and other things (the way interviews often go). Later, Jim would go on to run for the Tribal Council and get elected and then he would run for Navajo Nation President, lose in the primaries, and then be tapped as Ben Shelley's running-mate. Jim would then go on to serve as vice president of the Navajo Nation (his term only came to end in the spring of 2015), though the role of poet continued to be important to Jim. On April 3, 2015, at a poetry reading and while still vice president, Jim told the audience that, « I am a poet. I always say if I'm going to be defined as anything, it's a poet » (Silversmith 2015).

I want to go back to an October evening in 2000 and an interview I did with Jim overlooking the historically and culturally important place Tséyi' (also known as Canyon de Chelly) ${ }^{5}$. It was Jim's suggestion to do the interview outside that night at Tséyi'. Our interview was, ostensibly, to be about a poetry manuscript that Jim had shared with me. Though it seems now to me that Jim had certain things he wanted to talk about. The manuscript had been submitted to a press by the time Jim shared it with me. What was interesting about the manuscript, given Jim's reputation for writing in Navajo, was that it was mostly in English. There were no Navajo language poems in it. The title of the manuscript, spirit echoes spirit, hinted at the fact that Jim was attempting to do in English the kinds of things he had done in his Navajo poetry as well (that is, playing with the multiple senses of « spirit »). The poems worked in English because, as he said, they « pushed » English, just as some of his poems in Navajo « pushed» Navajo. They played with homophones and polysemous words and forms. They reveled in the poetic maxim: be ambiguous. I make this point because the press responded to Jim's manuscript by asking for the Navajo versions of the poems. They said they'd be happy to publish the manuscript but only with the Navajo versions. It goes without saying, but I guess I should say it, that there were no Navajo versions. Spirit echoes spirit has not been published. Jim had been typecast as the Navajo poet who wrote in Navajo.

a copy of his 1994 article when I was doing fieldwork on the Navajo Nation in 2000 and it has influenced much of my thinking.

5. For a discussion of Canyon de Chelly and some of the poetry associated with it see Webster (2009, p. 185-217) and Tohe (2005). 
Unlike many of the other poems by Jim that I have written about, the poem I discuss here does not come from Jim's (1995) all-Navajo collection saad. Instead, I first heard this poem (and another poem) during an interview with Jim in 2000. The poem would not be published, as far as I can find, until 2010. Then it was published in the Princeton Alumni Weekly (Jim's an alumnus) as a « web bonus » part of a feature on Jim and his emerging career as a politician (Bernstein 2010). The «web bonus », titled «What I Write About», contained, for a time, a video interview with Jim and a discussion of three poems (Jim 2010) ${ }^{6}$. Two of the poems were poems that Jim told me about in that October interview we did in 2000 . The third poem (actually the first poem performed by Jim on the video and in the written portion) is a revised version of a poem that appears in saad (Jim 1995, p. 22) ${ }^{7}$. Unlike the poems in saad, where there are no English versions, Jim (2010) does provide English versions for the three poems. Jim discusses, in some detail, the third poem - the one dedicated to Princeton's 200th anniversary - but does not say much about the first two poems. I will discuss in detail the second poem from that video and the text by Jim (2010). I will return to a discussion of the video performance and the publication version from 2010 later.

\section{« Fragile like a cobweb »: transcript and commentary}

Here I'd like to turn to several portions of the transcript of our interview that night. That night we had driven from Tsaile, AZ, over to Chinle, AZ, and had dinner at the Holiday Inn. We then drove to Canyon de Chelly National Monument, along the south rim drive and stopped at Tsegi overlook. It was a cool night; cloudless, the stars were out, an occasional breeze came through the canyon. The first spoken voice on the tape is mine and I note that one can see the Big Dipper in the sky. It was not the first time I had interviewed Jim, nor would it be the last. Once the interview begins, I start that night by foregrounding my dissertation research concerns - which were on language choice, language ideologies, and language and identity in and through poetry (Webster 2004) and asking him why he wrote the book in English. Jim responded by asking me, « Why not? » It was a good question and one I have often reflected on since

6. The video is no longer available at the Princeton site but can be found on YouTube at https://www.youtube.com/watch?v=Pk6ESQUmxm8, accessed 09/08/2016.

7. The poem in saad begins with the line dibé yikah léi' (Jim 1995, p. 22), which for purposes here glosses as « a group of sheep are walking, I realized». The poem in Jim (2010) begins dibe naakai lei' which Jim translates as « sheep wandering » (in the written version, the acute accent for high tone is not used). The attentive listener to the video will note that among the four basic clans that Jim identifies is his paternal grandfather's clan Naakaii dine'é « The Wandering People» (where the $-i$ is a nominalizing enclitic). Embedded in the first line of the poem, now, is an echo to one of Jim's clans. 
then. Elsewhere (Webster 2009, 2015a), I have very much been concerned about the heteroglossia found on and around the Navajo Nation and in the poetry written by Navajos (see also Field 2009; Peterson and Webster 2013). Poets write, as I have discussed, in Navajo, English, and Navajo English and various combinations (Webster 2009, 2015a). They write far less frequently, though it is spoken quite often, in what is called - among other things - Navlish (a merging of Navajo morphology and English lexical items) (see Webster 2009). Jim went on to tell me, after chastising me - rightly - for my question, that he was, « kinda to the point in my life that English is now a part of me ».

I will now present portions of the transcript with Jim. The presentation is organized into lines based on pausing (a blank line indicates a longer pause). I do this not to argue that Jim (or I) spoke in poetry that night but rather to give a sense of the cadence, the rhythm of the conversation. I will intersperse commentary that will clarify some of what Jim tells me. I don't claim to clarify all or even most of what Jim told me, but I hope enough to make my interpretations below sensible. I present the transcript so that others can also use it as a way to think through this poem and Jim's poetry more generally. I've left out certain parts of the transcript for the sake of space and because, while interesting, those portions might confuse the purpose of this article. (RLJ = Rex Lee Jim; $\mathrm{AKW}=$ Anthony $\mathrm{K}$. Webster)

RLJ: English allows me to go beyond what Navajo has to offer it offers new experiences new possibilities and when I switch to English what it also does for me is when I switch back to Navajo it says, « why not in Navajo in this area as well »

AKW: mhm

RLJ: so it allows me to push the Navajo language in those areas and in so doing I think I'm expanding the capacity of the language in many ways for one way come up with new vocabulary to to explain the possibilities in certain areas that didn't exist before and but exist in English and I think it's the same way the other way around English has its own limitations and boundaries and when I switch to English and I come to the realization that I can't push English beyond this 


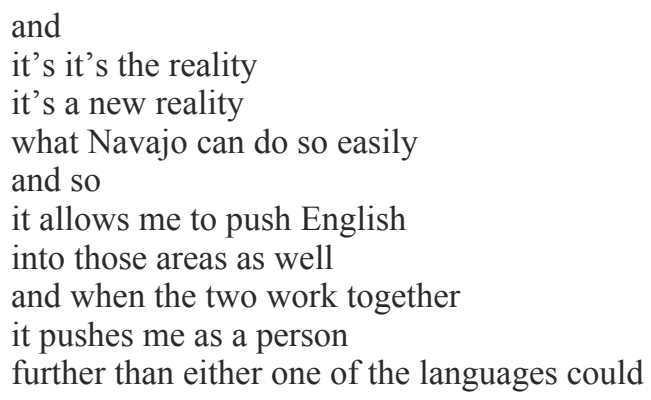

Let's just follow my interview with Jim a bit more. Inelegantly, I then ask Jim about something I've noticed in his poems - and something that Navajos including Jim - have begun to intimate to me as well - first in the English poems, but over time in the Navajo poems as well. I call it here alliteration - Jim takes up that term - and homophones - in more technical garb I've called it phonological iconicity, Navajos that I know call it saad aheett'éego diits ' $a$ ' « words that resemble each other by sound » or punning (Jim too will call it punning) (see Webster 2015a, 2015b, 2015c).

AKW: Well one of the things you do in the poems, at least that I saw, was that you use a lot of alliteration in a in the poems

a lot of homophones as well

words that sound same

you know

do you think that's an English thing or do you think a

alliteration is common in Navajo

RLJ: I think

alliteration, whatever that means [laughter]

is how the human mind works

it's sorta like associations

AKW: $\mathrm{mhm}$

RLJ: You think of something

tree

then you think of the branches

and that looks like broccoli

then it goes to broccoli

that looks like food

you know how it starts connected, I think

AKW: Right

RLJ: for me the alliteration it's something similar to that

that there's certain words

and yet they look like something else 
or they sound like something else

and there just connected different thoughts

and it's sorta like a spider web

seems like they're very connected

they're fine lines where

I guess in a sense

the whole idea, for me, of alliteration is like

something that's fragile like a cobweb

that

that you could read it one way

and have a totally different interpretation

but if you read it a different way

you'll have a different meaning, a different experience

and that life is like that

there are these interconnections

that

you go into a situation

you could think of it as hardship

or you could think of it as a great challenge

AKW: mhm

RLJ: you think of the situation and say

give up

or you could say

« how do I resolve this »

or go into a situation and say, um

« I can't do this. »

Or you could say, « this is a great chance for me to learn something new ».

There's always that.

And so I think of some these alliterations

works that way

allows you to go either this way or this way or another way

regardless of what will be up or down

but when you begin to

understand how that works

then you can go

any direction and come back to the center again

And I think for me the idea behind the earth is round

if you can go deep down into it

you get to the core where it's all the same

and if you know

if you get to the core you can surface on any part of the earth

and you'll understand the situation there

people always say you need to go beyond language, beyond culture

you need to go beyond the personal things to understand others 
I disagree with that

I think

we must go through culture and language

we must go through ourselves

to get to the core

AKW: mhm

RLJ: and that means going deep and within

and once we do that we can surface

anywhere

and understand

the heart of things

that

an example is the more and more Navajo I think I become

the more and more genuinely Navajo I think I become

AKW: mhm

RLJ: people like my work more

even though they're not Navajos

and I've come to the realization

that in doing that

I become more and more human

and when I get to the core of humanity

through my own language and my own

biases and prejudices and preferences

I come to realize

« hey, I'm a human being and this is who I am »

and what I speak and write out of that

others understand that

the language may be different

the images may be a little bit different

maybe more desert coyote images

but

when you really get to the heart of it

you ask them they say, « yes I understand that »

and so I think alliteration

allows

that to take place

if you want to get at the heart of the poem

then you can go either way

and

that's the way it is

AKW: mhm 
This image, of the linking of words through sound as « fragile like a cobweb », is a particularly compelling image. Jim argues that it is not by overcoming differences of language and culture, but only by diving deeply into them, that we can be reminded of our shared humanity. Notice also, while Jim calls it " alliteration », he is really talking about punning here and the intellectual value, the moral value, of punning. He makes this point again a short time later:

RLJ: and

so it

I think that one

so it is a conscious choice to really look at it

and the sounds too

that

and even in Navajo

Navajo is very good at

alliteration and puns

even the pronunciation

if you slightly pronounce it just a little bit

because it's a tonal language

you change the entire meaning of the whole thing

a lot of the poems in Navajo

are written that way

especially the smaller ones

I then ask Jim about why he uses the Navajo words sin « song » and saad « language, word» to bracket the English language poems in spirit echoes spirit. Here is part of what he tells me:

RLJ: Because saad

I guess you could translate it as word

AKW: mhm

RLJ: or language

AKW: $\mathrm{mhm}$

RLJ: or speech

but before that for me

saad means sound

sound that communicates

[car goes by loudly]

even if my eyes are closed the sound that just passed by

tells me

car went by

AKW: Right 
RLJ: and if you live way out in the country

you can even get to know the sound of vehicles

by hearing it you know who's coming

and it's the same way if somebody knocks at your door

sometimes you will know whose action by the way they knock

or whether if it's midnight and someone starts banging at your door

that tells you something

So for me it is

Sound

That conveys some sense of meaning

That communicate

Something that I

Perceive as meaningful

That

Affects me in some way

Even the sound of crickets [can be heard in background]

They remind me of whole history

They remind me of things that I've suppressed

And force me

To recall those and think them through again

Or it could remind me of happy times

And allow me to dance and smile

And so for me

Sound is the beginning of all things.

Another poet, Blackhorse Mitchell, once told me, when discussing the approach some linguists and anthropologists take to the Navajo language, that « the validity of Navajo is in its sounds, not in the neat things it does » (see Webster 2015a). Sound in these poems is quite important. Jim told me that as well in a later interview (see Webster 2006, 2015c). Indeed, he challenges the conventional translation of saad into English as « word, language » and argues instead that saad is « sound that communicates » and « sound that conveys some sense of meaning » and this meaning, as his example of crickets suggests, is not reducible to mere semantics. Indeed, the fact that we are outside, and we can hear both crickets and cars going by, affords Jim examples of the meanings of sounds. An interview inside would have, most likely, suggested different sounds. Notice that both Mitchell and Jim seem to argue against a view that disentangles sound from language, that denies the materiality of language (see also Reichard 1944; McAllester 1980). They argue for language as a sounded phenomenon (see Webster 2015a).

Where does poetry come from? I ask Jim how he writes his poems, where does the inspiration come from. Jim tells me there are, essentially, three ways that he composes poetry: 1 . he works and reworks them (call this the craft of poetry); 2. he hears other people say something and then writes it down (call 
this found poetry in the speech of others); and 3. they come to him by way of the Little Wind (nítch'i 'álts'íisí). Let me quote James McNeley (1981, p. 36) on Little Wind in Navajo philosophy, « it is these Little Winds sent by the Holy Ones that are thought to provide the means of good Navajo thought and behavior ». He goes on to note that, «Little Winds sent from the Holy Ones in the four directions work to strengthen the Wind within one towards the end that it will continue to be capable of helping the individual to lead a good life » (McNeley 1981, p. 49). Little Winds are messengers/messages from the Holy Ones (deities) to Navajos on proper moral behavior.

I should note that the messages from these Little Winds are « absolutely faultless » (ts'ídá ba'ádinii). McNeley (1981, p. 54) makes this point when he notes that:

the complex of behavioral traits subsumed by the term « being faultless » are a function of existing under the influence of aspects of Wind that are also faultless. This Wind is sent to the individual by deities such as Talking Gods and Calling Gods who are inner forms of the sacred mountains and who are themselves absolutely faultless.

Here it is well to reflect on Jim's description of those poems as « masterpieces $»$. The poems were with Jim long before he wrote them down. He recited them to friends and family. These poems, having come from Little Wind, resist any tampering with or reworking by Jim. They are complete unto themselves. He just needs to hear them, to recognize them. This hearing is done by not being « too egotistical or full of it». In this sense, these « masterpieces » aren't the work of Jim. He can't really take credit for them. He is, then, not the author of these « masterpieces », but their animator (see Goffman 1981, p. 144 on the distinction between « author » and « animator »).

Here's the relevant portion of the transcript from Jim (with a tin-eared question from me in the middle). Jim often enjoyed teasing me during interviews about the assumptions behind my questions. I've learned to appreciate the value of such teasing more and more over the years (see Webster 2009). I'll discuss in more detail the first poem Jim recites in the next section. Note that Jim does not translate the poems for me that night. He recites them only in Navajo.

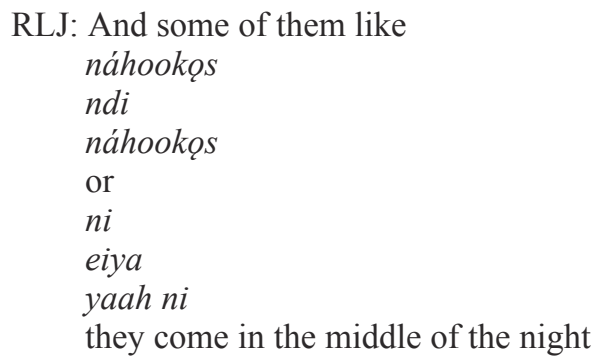


and you get up

and write them down

and the next day you try to improve on it

so you write several pages that doesn't work

you try to add or delete something

and it doesn't work

they just come

and they are considered masterpieces

you can't do anything to it

I've tried and it doesn't work

and in many ways I feel that it's not my work

because

they just appear

out of nowhere

and sometimes I think about what Navajos say about the Little Wind telling

you something [wind in background]

after so much experience

and so much trials and errors

that somehow your human mind is ready to receive something

from somewhere else

or maybe has already been there

but you were just too

egotistical or full of it

that you never allowed it to sink in [laughter]

I don't know how it works

all I know is it feels like somebody is telling you to

write it

and so some of them come like that

and so some of the poems like that

I don't know whether I can claim them or not

AKW: So when do you do your writing then?

RLJ: When I'm not being interviewed [laughter]

AKW: Okay. [laughter]

Besides when you are not being interviewed [laughter]

When do you write your poems?

RLJ: I have a notebook by my bed

Like sometimes ideas come to me in the middle of the night

I just wake up and write

Sometimes I write for the rest of the night

Or sometimes I just jot things down and go back to sleep

And sometimes I compose in my mind

And a poem is in my head for years before I write them down

I recite them, I redo it 
Just, um, like the one náhookos ndi náhookos

Like I said I hiked top of Lukachukai Mountains two in the morning with snow

February

And repeated that phrase

náhookos

ndi

náhookos

To actually look at it

And to then look down here

And what does it mean

And I'd try it out by myself

Or sometimes when I'm with friends

Or sometimes we have a cookout at night with my family

And I'd repeat it

náhookos

$n d i$

náhookos

What does the whole thing mean

What does it do to a person

And finally after so many years

Of saying that and doing creates

Okay, I'll write it down

So you write it down.

Lot of time

With these shorter poems come that way

I am struck in listening to the tape, and offer no theory and no explanation for it (other than, of course, that winds blow through canyons), by the wind that breezes through the canyon as Jim mentions « Little Wind ». The Lukachukai (Lók'a'ch'égai) Mountains run north and south along the New Mexico and Arizona border. They are a prominent feature on the landscape. Navajos that I know have sacred places, places where they go to pray and to contemplate, in those mountains (see Kluckhohn and Leighton 1962, p. 204; Kelley and Harris 1994, p. 42-46).

\section{Creative transposition: náhookǫs ndi náhookos}

I want to interrupt the transcript and discuss the first poem he recites; extracted and artifacted from the flow of the interview I did with him and based on my transcription of the Navajo. I'll return to the transcript in the next section when I ponder something like an interpretation of this poem. I present the poem from the first time he recited it that night. In transcribing the poem, I have followed 
the Navajo orthography found in Young and Morgan (1987). It is also the orthography that Jim often uses.

Before we look at the poem, let me also say something more about the phonology and prosody of this poem. Understanding that phonological descriptions are always only partial (see Port and Leary 2005), this will stand as an approximation for the sounds of the poem: $/ \mathrm{n} /$ is an alveolar nasal stop (which repeats at the beginning of each line), /á/ is a high tone low back vowel, $/ \mathrm{h} /$ is a voiceless glottal fricative, /oo/ is a long mid back vowel, $/ \mathrm{k} /$ is an aspirated velar stop, /Q/ is a nasal mid back vowel, /s/ is a voiceless alveolar fricative, /t/ is an unaspirated alveolar stop (this is written as $<\mathrm{d}>$ in the standard orthography and I follow that convention here), and /i/ is a high front vowel (see Young and Morgan 1987, p. XII-XV; McDonough 2003a). As for prosody, Navajo does not have stress (McDonough 2003b; Kidder 2008). Instead, prominence - « generally some combination of the amplification of duration, intensity, and local pitch perturbances such as pitch range expansion $»-$ aligns with the verb stem (the most semantically salient content morpheme and also often the rightmost content morpheme) (McDonough 2003b, p. 204) ${ }^{8}$. Prominence occurs on the verb stem $-k o s$ in lines one and three. The particle ndi that makes up line two does not take prominence. Because of this rightmost prominence on the verb stem, in both my tape-recording and in the performance of the poem for Princeton, the poem seems punctuated by the repetition of -kos. These are all, or should be, considerations in attuning to the music - the phonosonic nexus - of the poem.

In the presentation of the poem, lines have been separated based on pause structure (pause equals line break) and coincide with words (note that the second time he recites the poem that night, he does not pause at all during it - thus creating a single line; but the next two times he recites it, he does pause after each word).
náhookos
ndi
náhookgs

I now want to present how the poem is written in Jim (2010):

nahookos
nidi
nahookos

8. Joyce McDonough (2003b, p. 204-205) argues that this prominence is a result of the conjunction of Navajo being both a pronominal argument language and tending towards SOV word order. She notes, and it is well to remember this, that not all Athabaskan languages are pronominal argument languages and therefore may have, unlike Navajo, developed stress systems and tonal intonations. Translating this poem into one of those Athabaskan languages might then change the prosodic structuring of the poem. 
Notice that in the Princeton version the nasal hook and acute accent for high tone are not used. In another poem that Jim (1995, p. 45) wrote concerning náhookos in saad he writes náhookos ${ }^{9}$. I think it likely that the Princeton website did not have the capacity to present the diacritics. In any event, the poem is performed on the video by Jim with a high tone on the first vowel /á/ and nasality on the final vowel $/ Q^{/ 10}$. Another difference is between $n d i$ and nidi. On the tape that I have of the interview with Jim, I am relatively certain that I hear ndi and not nidi (though the two forms are very close in sound and so I will never have absolute certainty, nor do I think certainty is needed). On the video from Princeton, it also sounds like ndi (but I am, again, less than certain). Both forms I have been told by Navajos that I have asked about it can be used as a contradictory particle and Jim translates it that way as « even ». Indeed, Robert Young and William Morgan (1987, p. XV) point out that the syllable/ni/ is often reduced to syllabic $/ \mathrm{n} /$ and give as one of their examples of this process: $n i d i=n d i$ «but ». I think, however, Jim spelling the word in its full form is not accidental and I will return to that point later. Here it is well to remember that while spoken poetry has sonic form, written poetry - whether it is read aloud or not - has visual form (see Becker 1995, p. 195-197) ${ }^{11}$. A compromise of formats might be to include the diacritics (for high tone and nasality) and to represent the particle in its full form:

\section{náhookos \\ nidi \\ náhookos}

Having discussed the visual and sonic form of the poem, let us turn to something of the twining of sound and sense. According to both Navajos I have talked to about this and to various bilingual dictionaries of Navajo to English, náhookos can be translated any number of ways into English. First, as to the morphology: náhi- seriative, one after another (here likely in the progressive aspect as náhoo-) + -kos (this is the verb stem -kęéz « slender stiff or thin rigid object, falling or flying through air » or a « slender solid object revolves » [see Young and Morgan 1987, p. 542]). And while the morphology is certainly important, Jim would make this point to me in another interview, after all, as he told me, he was trying to get people to think about etymologies; we should not

9. That poem can be glossed as follows: "náhookos / náábat / nák'eeshto' / diłdas » (Big Dipper-north-gyre / is spinning / making tears / drip) (Jim 1995, p. 45). The glossing of this poem was done in consultation with Rex Lee Jim, Blackhorse Mitchell, as well as other Navajos. I thank them all for their insights.

10. The poem is performed on the video at around minute 1:43.

11. This is not a trivial point for some Navajos, I might add. One criticism of the current Navajo orthography that I have heard is that it « looks like English » (see Webster 2012). This is also, sometimes, given as a reason for not using the orthography (Webster 2012; see also Webster nd). 
think that discerning the morphology tells us everything about the work of this poem (see Mitchell and Webster 2011 on this point). The form is conventionally translated into English as « north », « turn », « Big Dipper », or the geometric shape of the swastika (see Young and Morgan 1987, p. 542). Jim and I, in a later interview, translated its use in another poem as « gyre " (influenced, as we were, by a poem by W.B. Yeats - « The Second Coming » - that we had been talking about). It can be understood as both a verb and/or a noun. Thinking about it as only a noun can be misleading.

A number of years ago, Clyde Kluckhohn and Dorothea Leighton discussed some of the linguistic issues concerning náhookqs. Here is what they wrote:

$[\mathrm{T}]$ here is enough idiom in Navaho to make a literal etymological translation meaningless in many cases. For instance, náhookos (north) translates literally as « one stiff slender object makes a revolution » (from the constellation of the dipper which revolves around the North Star). For purposes of conveying meaning the etymology does not matter, and such a rendering would merely compound confusion - to say the least - save for the purposes of the scientific linguist.

This not to say that etymology is irrelevant to all nuances of communication. While it would be absurd to pretend that the whole etymology of náhookos is present to the consciousness of a Navaho every time he says the word, still the sheer formal nature of the verb as well as the meanings of its separable elements must carry with them a background of association and connotation that is altogether lacking in the English noun « north ». (Kluckhohn and Leighton 1962, p. 289)

While I agree about the dangers of literal translations, it is important to realize that náhookos is also used as a verb in everyday expressions. Young and Morgan (1987, p. 542), for example, give the following example sentence (I’ve bolded náhookos):

\section{Tsinaabąas shit yilwołgo teezh bee hahalkaadi 'ii' sitánęę hááhgóóshịi náhookgs}

As I ride along in the wagon, the shovel lying inside is really turning around and around

Here náhookos is used to describe the movement of the shovel. Note as well that Kluckhohn and Leighton reduce the meaning of náhookos to only « north » and this misses the other senses of the form (for example, the geometric shape swastika or the Big Dipper). In certain contexts, then, náhookos can be used as either a verb or a noun and the meaning of the noun is polysemous ${ }^{12}$. It is

12. This differs, I might add, from other Southern Athabaskan languages. In Western Apache, for example, the form is náhokosé « the stiff slender object that revolves around » or « Big Dipper » (Bray 1998, p. 296). This form, while clearly cognate with the Navajo term, adds the nominalizing enclitic -é. The nominalizing enclitic, which Navajo has, is not used for náhookos. Interestingly, as well, the Western Apache term for something akin to " north » is hadaazhi' (Bray 1998, p. 398). Here we see the limits of translating the poem 
also important to remember that for Jim, getting Navajos to think about the « semantics and etymology » of words was a part of the goal of his poetry. As Jim pointed out to me in another interview, " most of my poems are written to stimulate thoughts, and that involves thinking about semantics and etymology » (see Webster 2006, p. 44). It is the polysemy here that Jim seems most interested in exploiting. We should not assume that only the " scientific linguist» is interested in etymologies. Navajos that I know often enjoy speculating about word affinities and etymologies (see Webster 2009; Peterson and Webster 2013).

$N(i) d i$ can be translated as the contradictory « even » or «but » (see Reichard 1951, p. 328) - though I have a sense that it can also be heard as $n i$ 'di « on earth » ( $n i$ '- « earth »+ $-d i$ « at, on » locative enclitic indicating less proximate and more general [see Young and Morgan 1987, p. 18]) ${ }^{13}$. The first poem in spirit echoes spirit seems a paraphrase of this poem and seems to confirm as well my suspicion about « on earth »:

even big dipper turns,

turns,

turns on earth. (Jim nd, p. 4)

« On earth » makes sense if we hear the pun between $n(i) d i$ and $n i$ 'di. Jim's writing out of the full form makes the resemblance between nidi and ni'di more acute. If we accept the possibility of a pun between $n(i) d i$ and $n i$ 'd $i$ and combine it with the polysemous quality of náhookos we realize that every line in this poem is ambiguous.

Here's my attempt at a creative transposition:

\begin{tabular}{|c|c|c|c|c|c|c|c|c|c|}
\hline north & gyre & gyre & $\begin{array}{c}\text { big } \\
\text { dipper }\end{array}$ & gyre & north & $\begin{array}{c}\text { big } \\
\text { dipper }\end{array}$ & $\begin{array}{c}\text { big } \\
\text { dipper }\end{array}$ & north & north \\
\hline even & even & even & even & even & even & even & even & even & even \\
\hline gyres & gyres & $\begin{array}{c}\text { big } \\
\text { dippers }\end{array}$ & gyres & norths & $\begin{array}{c}\text { big } \\
\text { dippers }\end{array}$ & $\begin{array}{c}\text { big } \\
\text { dippers }\end{array}$ & norths & norths & gyres \\
\hline
\end{tabular}

I've tried to highlight the multiplicity of meanings of náhookos and the way that the poem seems to turn on itself (hinting here at the seriative). What I have sacrificed in quickness ${ }^{14}$ (one of the deficiencies here) and sound (gone is the recurrent alveolar nasal stop line initial, gone too the prominence of the verb stem, gone as well many of the sounds in the Navajo version, including the

from Navajo into a closely related language such as Western Apache. I thank David Samuels for his insights into Western Apache on these points.

13. / / is the glottal stop and is produced in a manner similar to the catch in the throat when saying $u$ h-oh.

14. For a discussion of « quickness » see Calvino 1988 (see also Webster 2006). 
consistent echo of the first and third line), I hope to have compensated for in an exuberance that highlights the complexity, the ambiguity, of some of this poem. For now, anyway, I leave $n(i) d i$ consistently translated as « even ». In attempting to capture something of the simultaneity of the verb-ness and nounness of náhookos in my version, I have treated the third line as verbs, where $-s$ is an agreement marker for the third person singular noun. Of course, the $-s$ can also be read as a plural marker and thus a new kind of ambiguity is introduced. I use « gyre » because it can be used as both a noun and verb, has a particular sound sense that I find pleasing here, and also because it reminds me of another poem that Jim and I worked on where we used " gyre » for náhookqs.

Let us consider, briefly, Jim's three versions of this poem in English. The first version is the version from spirit echoes spirit:

even big dipper turns,

turns,

turns on earth. (Jim nd, p. 4)

Above, I called this a paraphrase. It does seem to paraphrase some of the semantic content of the Navajo poem and it makes explicit, perhaps, a pun that works in Navajo but does not work in English $(n(i) d i \approx n i$ 'di). " Turns » is repeated three times in the poem, but the fulcrum $n(i) d i$ is moved to the beginning of the poem ${ }^{15}$. While Jim is able to keep at least one alveolar nasal stop in each line, it does not pattern the same as in Navajo (where it occurs word initial). Gone too are $/ \mathrm{a} /, / \mathrm{h} /, / \mathrm{oo} /, / \mathrm{k} /, / \mathrm{Q} /, / \mathrm{t} /$, and /i/. The poem, not surprisingly, sounds radically different. Added, are a whole host of sounds, including the voiced alveolar stop /d/, which does not occur in Navajo (the Navajo practical orthography writes the unaspirated alveolar stop $/ \mathrm{t} /$ as $\langle\mathrm{d}\rangle-$ this sometimes leads to confusion for people trying to learn Navajo) and the voiceless interdental fricative $<$ th $>$. Added too is the aspirated voiceless alveolar stop $/ \mathrm{t}^{\mathrm{h}} /$ (written here as $<\mathrm{t}>$ ) that is found in Navajo (but not in Jim's poem) and contrasts with the unaspirated voiceless alveolar stop / $\mathrm{t} /$ (written here as $<\mathrm{d}>$ ). English stress patterns (which are variable) differ as well from the rightmost prominence found on the verb stem in Navajo. In English, words take stress and there is no tendency for rightmost

15. One reviewer noted that Jim seems to be focused on carrying over the semantics of the poetry here and not the phonosonic nexus. Though, as that reviewer notes, the repetition of « turns » does create a particular phonosonic constellation in Jim's creative transposition. The reviewer asks why repeat « turns » three times here. To that, I am unsure. As many have noted, see for example Webster (2009), things tend to be repeated two or four times in Navajo poetic discourse. Three does seem interesting here. Rhetorically, repetition four times often indicates completion in Navajo. The repetition three times may suggest, then, incompleteness. As to the point about the precedence that Jim gives to meaning over sound in his creative transpositions, it is, as the reviewer notes, unexpected. Perhaps, given that it was a masterpiece, attempts to recreate the phonosonic nexus in English would have been, by definition, impossible. That, though, is merely a suggestion. 
prominence. Thus the very rhythm of the poems is different. The mouth seems - especially in the first line - busier when reciting the English version.

The ambiguities are different as well. Lost is the polysemy associated with náhookos. « Even », on the other hand, has its own polysemy and ambiguity (e.g., " even money »). " Big dipper », which provides a descriptive image of the asterism, is not the same image as evoked in náhookos. Three words in Navajo are converted into eight words in English. Like my version, there is an exuberance of words in the English version. Jim's version is best considered a creative transposition - it is a poem in English that was inspired by the Navajo poem. Paraphrase then seems the wrong term. It is, instead, a poem in English that has resonances - mostly semantic, not sonic - with a poem in Navajo.

Here are the next two versions. The first is how Jim (2010) translates the poem in writing. The second is how Jim translates the poem on the video.

\author{
big dipper \\ even \\ turns. ( Jim 2010) \\ even \\ the big dipper \\ turns
}

Both these versions seem minimalist. The first version matches exactly the word order of the Navajo version (though it cannot maintain the repetition of the same word in the first and third line). It uses the asterism « big dipper » - which has its own ambiguities in English (that is, it can be heard as not an asterism). As with the previous example, it sounds and feels (when saying) different than the Navajo version. One obvious example is that the first line and the third line do not echo each other given their identical form in the Navajo version. Like the above example, it introduces its own ambiguities. For example, besides the polysemy of « even », we can also think about the myriad senses of « turns » in English. One sense, that of « revolving », seems to align with something of náhookos (the slender stiff object sense seems missing in « turns »), but « turns » also adds a sense of « becoming » (e.g., " he turned into a frog ») that seems, at least in my understanding of náhookos, absent (see, for example, Young and Morgan 1992, p. 323-325). As Becker (1995), following Ortega y Gasset (1959), has noted, translations are always exuberant (adding in more than was in the original) and deficient (leaving out much as well). This sense of « turns » as « becoming » seems exuberant when compared to the Navajo version. Much the same could be said for the third version as well. Here, though, Jim rearranges the word order and adds the article « the ». Navajo does not use articles. The English article «the » is exuberant here.

I make these points, not to criticize Jim's English versions but rather to call attention to the art of failure in «translating » poetry. My own creative 
transposition is also a failure. Yet, I have learned much about English and Navajo - about their respective attunements - in reflecting on how one might translate the poem into English. There is value - aesthetic and intellectual value - in such practices, such contemplations.

\section{« And I will not tell you all about that »}

What then to make of this poem? To make of this « masterpiece » that might well have been given to Jim by the Little Wind? North, like many things in Navajo philosophy, is polyvalent. On the one hand, the north is routinely associated with death (see Kluckhohn and Leighton 1962, p. 184). On the other hand, there is also a view that north is associated with old age and with reflection and assurance. With the ability to recognize what you have done in life. North in this way of thinking is associated with moral judgment, the ability to recognize good and evil (Aronilth 1991, p. 98). And then, of course, the whole thing repeats. You take what you've learned and begin again. Here is how Vincent Werito (2014, p. 27) describes it:

The Diné philosophy is associated with and orientated to the four cardinal directions, starting with the east direction... so in relation to human life, this process of orientation for living and learning guides how an individual lives and develops respect and/or reverence for self, his or her relatives, and the natural world. These four aspects of the Diné philosophy of learning and living are Nitsáhákees (Thinking), Nahat'á (Planning), Iiná (Living), and Siihasin (Assurance), in respective order. These four aspects of Diné philosophy are understood to represent life principles that guide our processes of thinking or conceptualization, planning or self-actualization, doing by establishing relationships with others, and reflecting or being self-reflective and aware of others and the natural spiritual world.

Deborah House (2002, p. 96) discusses it in the following manner:

This four-direction cycle concludes with the north, only to begin again with nitsáhákees in the east. North is associated with old age, folding darkness or night, the sacred Obsidian Mountain, Dibé Ntsaa (Hesperus Peak or La Plata Mountain in Colorado), winter, and sihasin, which means « to make strong and stable, to secure, to develop confidence, and to have a clear path ». It is in the sihasin stage that you will learn whether your thinking, planning, and implementation were successful. If they were, you will want to replicate and maintain what you have accomplished, perhaps making adjustments based on your evaluation of what you have done. This is also the state in which you will recognize the consequences of errors or neglect in your previous states. When the cycle is repeated, you will know what to do differently to remediate the problems or errors.

What of the resonances with the Big Dipper? How might we think of the Big Dipper within Navajo philosophy? First, here is a version of the myth of the 
origin of the asterism the Big Dipper as told to Washington Matthews (1994 [1897], p. 223-224):

The following is the tale as told by Náltsos Nigéhani: « Now First Man and First Woman thought it would be better if the sky had more lights, for there were times when the moon did not shine at night. So they gathered a number of fragments of sparkling mica of which to make stars, and First Man proceeded to lay out a plan of the heavens, on the ground. He put a little fragment in the north, where he wished to have the star that would never move, and he placed near it seven great pieces, which are the stars we behold in the north now. "

Trudy Griffin-Pierce (1992, p. 153) in her discussion of Navajo astronomy notes that, like much in Navajo philosophy, there is a male náhookos bika'ii (« male one who revolves » or Big Dipper) and a female náhookos ba'áadii («female one who revolves » or Cassiopeia). Though conventionally, náhookos used alone denotes, among other things, the asterism we call the Big Dipper ${ }^{16}$. Here is what one of Griffin-Pierce's (1992, p. 153) consultants said about náhookos:

Chanter A... « They tell us [by their example] to stay at home, to stay around your fire ». Here the implication is that these constellations set a moral example for the Earth Surface People to remain home to carry out their familial responsibilities.

Chanter A offered a slightly different interpretation of these same constellations at an interview held three months previously. Then he had referred to the two Náhookǫs as leaders, as sources of wisdom and knowledge always available to the Earth Surface People; they are also visual reminders to leaders on earth that they must always be willing and ready to help their people.

Not surprisingly, other chanters - ritual specialists - give different interpretations of náhookos (see Griffin-Pierce 1992, p. 153-156). What interests me about Chanter A's analysis is that it resonates with the conversation I had with Jim that October night. It is the visual reminder that interests me here. Jim tells me that after the poem came to him he climbed to the top of the Lukachukai Mountains in the winter (associated, as it is, with náhookos) at two in the morning. On top of the mountain, he was able to actually observe náhookos (as, I might add, we were that night in October) as he repeated the poem. Standing on earth, he could see náhookos and he could reflect on what it might mean. All these considerations (and certainly some I am not aware of as well), however, have acutely influenced my creative transposition.

16. The interested reader is encouraged to consult Cannon and Holton (2014) on Northern Athabaskan asterisms and the concept of the «whole-sky constellation » or, in Gwich'in yahdii - « envisioned as a tailed man crouching face down above the earth with head turned toward his right and holding a crooked knife in his left hand » (Cannon and Holton 2014, p. 2). In this conceptualization, which differs from Navajo conceptualizations, the Big Dipper is the tail (vitsi') of yahdii. 
Here's what Jim said on the meaning of some of his poems that night:

\author{
RLJ: There's always \\ the poem presents and identifies a problem \\ I shouldn't say always \\ many of the poems \\ identifies a problem and at the same time offers a solution of something \\ and I will not tell you all about that [laughter] \\ you have to come to that yourself [laughter]
}

That seems fair and echoes with what other Navajos have told me about not forcing an interpretation on others (see Mitchell and Webster 2011; Webster 2015a). I don't want to force an interpretation here either. My creative transposition has suggested something of an interpretation (as it must).

I should add that Jim was talking, in the above excerpt, not just about the poems that come by way of Little Wind, but also the found poems he writes and the poems he crafts. Here and in other conversations with Jim, I take him to be suggesting, to adapt a phrase from Kenneth Burke (1974), poetry as equipment for living (see also Becker 1999). Poetry, in this view, won't make you more moral, but it might make you more reflexive, more aware of your humanity and the humanity of others. Ultimately, you must « come to that yourself » (see also Webster 2015c, p. 287-288). In this view, I hear echoes of W.H. Auden's introduction to The Poet's Tongue:

Poetry is not concerned with telling people what to do, but with extending our knowledge of good and evil, perhaps making the necessity for action more urgent and its nature more clear, but only leading us to the point where it is possible for us to make a rational and moral choice. (Mendelson 1977, p. 329)

Jim's poems, then, act as equipment for living. They present to Navajos possibilities for reflection and these possibilities, I would add, are bound up in the puns, the sounds, of the poems. The poems do not force one to be moral, but they make moral choices possible. Ultimately, as some Navajos say, $t$ 'áá $b i$ bee bóholniíh « it's up to her/him to decide » (see Mitchell and Webster 2011; Webster 2015a; Lamphere 1977; Rushforth and Chisholm 1991). People must make their own decisions.

Let me turn, finally, to how our conversation that October evening ended, with Jim reflecting on the three ways he wrote poetry in Navajo and on how that might work in English as well.

RLJ: At least that's how the Navajo ones come about I don't know about the English Maybe something similar

Here, it seems, is a suggestion that some English language poems may also be messages from the Little Wind. Afterward, I packed up my tape-recorder, 
dropped Jim at his truck, and then I drove, under a clear starry night sky, back to my little cabin north of Lukachukai.

\section{Conclusions}

As anthropologists, we must be willing to admit to our failures of translation (see Fabian 1995; Webster 2017). We should also be explicit about our creative transpositions, the art of our failures. Such explicitness should be predicated on attending to « the music and mechanics of the text » (Leavitt 2006, p. 104). This is the work of a thick translation or philological anthropology. It is the work I have engaged in here. In such work, we catch a glimpse of what Becker (1995, p. 397) called the « attunement over time » of every language, « a unique way of sounding, shaping, remembering, interacting, and referring ».

In this article I have tried to show the value of attending to the « unique way of sounding » of a poem in Navajo and how those sounds, especially in the twining of sound and sense and in punning, make translating poetry impossible. I have come down squarely on the side of Roman Jakobson (1959, p. 238) when he states that « poetry by definition is untranslatable ». I have made this argument based both on the use of punning in poetry, but relatedly on the materiality, the phonosonic nexus, of poetry. While I have focused exclusively on poetry, the argument concerning the materiality and muscularity of language - its phonosonic nexus - extends well beyond poetry to all language in use (see Samuels and Porcello 2015). The poetic function, for example, does not exist exclusively in poetry. While recent concerns with voice have not focused on questions of translation, I think it important that the insights from that research be applied to considerations of translation as well. Such a consideration brings into relief the ofness of language, its materiality, its physicality, its muscularity. The voice - the phonosonic nexus - of a language matters. No two languages share the same phonetic clothing, the same twining of sound and sense. No two languages permit the same ambiguities based on puns, on phonological iconicity. We must take seriously the phonetic clothing - the sounds - of languages and the imaginative work such clothing allows and inspires. As Dwight Bolinger (1949, p. 56) beautifully noted:

The phonetic elements of a language are like the keys of a piano. They have been played so often and in so many combinations that even a random chord, struck by an object accidentally falling on them, will have some vague semblance of meaning.

This is another way of restating Jakobson's (1959, p. 238) point, that « phonemic similarity is sensed as semantic relationship ». Or as Rex Lee Jim told me that October evening, " sound is the beginning of all things ». *

\footnotetext{
* Manuscrit reçu en janvier 2016, accépté pour publication en mars 2016.
} 
Acknowledgements - I would like to thank the numerous Navajos who have talked with me about issues concerning language and poetry over the years. I have especially benefitted from the insights of Rex Lee Jim, Blackhorse Mitchell, and Sherwin Bitsui. Fieldwork on the Navajo Nation was conducted in 2000-2001 and again in the summers of 2007-2012. All research on the Navajo Nation was done under permits from the Navajo Historic Preservation Office. I thank them. Funding for this research was provided by Wenner-Gren, the Phillips Fund of the American Philosophical Society, the Jacobs Grant from the Whatcom Museum, a Faculty Seed Grant from Southern Illinois University at Carbondale, and the University of Texas at Austin. I thank them all. I thank Aimee Hosemann, Juan Luis Rodríguez, Natalia Bermudez, David Samuels, Luis Cárcamo-Huechante, and Courtney Handman for a number of useful conversations about topics taken up in this paper. I thank Caitlin O'Neil for some last minute help. Portions of this paper were presented at the 2015 Denver, CO, AAA session on Navajo Expressive Culture organized by Kristina Jacobsen. I thank her for the invitation and for the comments by Ana Ochoa there as well. I thank as well two reviewers for Journal de la société des américanistes for a number of useful suggestions.

\section{References cited}

AppIAн Kwame

1993, « Thick translation », Callaloo, 16 (4), p. 808-819.

Aronilth Wilson

1991, Diné bi bee' Óhoo 'aah Bá Silá: an introduction to Navajo philosophy, Navajo Community College Press, Tsaile (AZ).

BAHR Donald

1983, « A format and method for translating songs », Journal of American folklore, 96 (380), p. 170-182.

BAUMAN Richard and Charles BRIGGS

2003, Voices of modernity: language ideologies and the politics of inequality, University of Cambridge Press, Cambridge.

BECKER Alton

1995, Beyond translation: essays toward a modern philology, University of Michigan Press, Ann Arbor.

BECKer Andrew

1999, « Poetry as equipment for living: a gradual reading of Vergil's ninth eclogue », Classics Ireland, 6, p. 1-22.

BERNSTEIN Mark

2010, «The poet as politician », Princeton Alumni Weekly [online], 111 (3), https:// paw.princeton.edu/article/poet-politician, accessed 07 June 2016.

BOLINGER Dwight

1940, « Word affinities », American Speech, 15 (1), p. 62-73.

1949, « The sign is not arbitrary », Boletín del Instituto Caro y Cuervo, 5, p. 52-62.

1950, « Rime, assonance, and morpheme analysis », Word, 6, p. 117-136.

Bray Dorothy (ed.)

1998, Western Apache-English Dictionary, Bilingual Press, Tempe. 
Burke Kenneth

1974, The philosophy of literary form: studies in symbolic action, University of California Press, Berkeley.

CALvino Italo

1988, Six memos for the next millennium, Vintage Press, New York.

CAnNon Chris and Gary Holton

2014, «A newly documented whole-sky circumpolar constellation in Alaskan Gwich'in », Arctic Anthropology, 51 (2), p. 1-8.

CIARDI John

1961, « Translation - The art of failure », Saturday Review, Oct. 7 1961, p. 17-19.

Diffloth Gérard

1976, « Expressives in Semai », in Philip N. Jenner, Laurence C. Thompson and Stanley Starosta (eds.), Austroasiatic studies, University Press of Hawaii (Oceanic Linguistics, Special Publications, 13), Honolulu (HI), vol. 1, p. 229-248.

DURBIN Marshall

1973, « Sound symbolism in the Mayan language family », in Munro S. Edmonson (ed.), Meaning in Mayan languages, The Hague, Mouton, p. 23-49.

FABIAN Johannes

1995, «Ethnographic misunderstanding and the perils of context », American Anthropologist, 97 (1), p. 41-50.

Feld Steven, Aaron Fox, Thomas Porcello and David Samuels

2004, « Vocal anthropology: from the music of language to the language of song ", in Alessandro Duranti (ed.), A companion to linguistic anthropology, Blackwell Publishing, Malden (MA), p. 321-345.

FIELD Margaret

2009, « Changing Navajo language ideologies and changing language use », in Paul Kroskrity and Margaret Field (eds.), Native American language ideologies: beliefs, practices, and struggles in Indian Country, University of Arizona Press, Tucson, p. 31-47.

FRIEDRICH Paul

1979, Language, context, and the imagination, Stanford UP, Stanford.

1986, The language parallax, University of Texas Press, Austin.

1998, The music in Russian poetry, Peter Lang, New York.

GAL Susan

2015, « Politics of translation », Annual Review of Anthropology, 44, p. 225-240.

GeLl Alfred

1979, « The Umeda language poem », Canberra Anthropology, 2 (1), p. 44-62.

GOFFMAN Erving

1981, Forms of talk, University of Pennsylvania Press, Philadelphia.

GrifFIn-Pierce Trudy

1992, Earth is my mother, sky is my father, University of New Mexico Press, Albuquerque. HANKS William

2015, « The space of translation », in Carlo Severi and William Hanks (eds.), Translating worlds: the epistemological space of translation, Hau Books, Chicago, p. 21-50. 
HANks William and Carlo SEverI

2015, « Translating worlds: the epistemological space of translation », in Carlo Severi and William Hanks (eds.), Translating worlds: the epistemological space of translation, Hau Books, Chicago, p. 1-20.

HARKNESS Nicholas

2013, Songs of Seoul: an ethnography of voice and voicing in Christian South Korea, University of California Press, Berkeley.

House Deborah

2002, Language shift among the Navajos, University of Arizona Press, Tucson.

HyMEs Dell

1960, « Phonological aspects of style: some English sonnets », in Thomas Sebeok (ed.), Style in language, MIT Press, Cambridge (MA), p. 107-131.

1981, In vain I tried to tell you, University of Pennsylvania Press, Philadelphia.

2003, Now I know only that far, University of Nebraska Press, Lincoln.

JACOBSEN Kristina

2014, « Radmilla's voice: music genre, blood quantum, and belonging on the Navajo nation », Cultural Anthropology, 29 (2), p. 385-410.

JAKOBSON Roman

1959, « On linguistic aspects of translation », in Brower Reuben (ed.), On translation, Harvard UP, Cambridge, p. 232-239.

1960, « Concluding statement: linguistics and poetics », in Thomas Sebeok (ed.), Style in language, MIT Press, Cambridge (MA), p. 350-373.

Jim Rex Lee

1989, Áhí Ni' Nikisheegiizh, Princeton Collections of Western Americana, Princeton. 1995, Saad, Princeton Collections of Western Americana, Princeton.

1998, Dúchas Táá Kóó Diné, Au Clochan, Beal Feirste (Ireland).

2010, « What I write about », Princeton Alumni Weekly [on-line], 111 (3), web bonus, https://paw.princeton.edu/issues/2010/11/03/pages/8440/index.xml, accessed 07 June 2016.

nd, Spirit echoes spirit, unpublished ms. in author's possession.

KEESING Roger

1989, « Exotic readings of cultural texts », Current Anthropology, 30 (4), p. 459-478.

Kelley Klara and Francis HARRIS

1994, Navajo sacred places, Indiana UP, Bloomington.

KIDDER Emily

2008, « Tone, intonation, stress and duration in Navajo », Coyote papers: working papers in linguistics, 16, p. 55-66.

KLuckhohn Clyde and Dorothea Leighton

1962, The Navajo, Doubleday, New York.

KozAK David (ed.)

2012, Inside dazzling mountains: Southwest native verbal art, University of Nebraska Press, Lincoln.

KUNREUTHER Laura

2014, Voicing subjects: public intimacy and mediation in Kathmandu, University of California Press, Berkeley. 
LAMPHERE Louise

1977, To run after them: cultural and social bases of cooperation in Navajo community, University of Arizona Press, Tucson.

LEAVITT John

2006, « Thick translation: three soundings », in Catherine O’Neil, Mary Scoggin and Kevin Tuite (eds.), Language, culture and the individual, Lincom, Muenchen, p. 79-108.

2015, "Words and worlds: ethnography and theories of translation », in Carlo Severi and William Hanks (eds.), Translating worlds: the epistemological space of translation, Hau Books, Chicago, p. 259-294.

LEVINSON Stephen

2003, « Language and mind: let's get the issues straight! » in Dedre Gentner and Susan Goldin-Meadow (eds.), Language and mind: advances in the study of language and thought, MIT Press, Cambridge (MA), p. 25-46.

MATTHEws Washington

1994 [1897], Navaho legends, University of Utah Press, Salt Lake City.

McAllester David

1980, "The first snake song », in Stanley Diamond (ed.), Theory and practice: essays presented to gene weltfish, Mouton, New York, p. 1-27.

McDonough Joyce

2003a, The Navajo sound system, Kluwer Academic Publishers, Dordrecht.

2003b, « The prosody of interrogative and focus constructions in Navajo », in Carnie Andrew, Harley Heidi and Willie Maryann (eds.), Formal approaches to function in grammar, John Benjamins, Amsterdam, p. 191-206.

McDowell John

2000, «Collaborative ethnopoetics », in Kay Sammons and Joel Sherzer (eds.), Translating Native Latin American verbal art, Smithsonian Press, Washington (DC), p. 211-232.

McNeley James

1981, Holy wind in Navajo philosophy, University of Arizona Press, Tucson.

Mendelson Edward (ed.)

1977, The English Auden: poems, essays, and dramatic writings 1927-1939, Faber and Faber, London.

Mitchell Blackhorse and Anthony K. WeBSTER

2011, " "We don't know what we become:” Navajo ethnopoetics and an expressive feature in a poem by Rex Lee Jim », Anthropological linguistics, 53 (3), p. 259-286.

NuCKOLLS Janis

1999, « The case for sound symbolism », Annual Review of Anthropology, 28, p. 225-252.

2000, « Spoken in the spirit of gesture: Translating sound symbolism in a Pastaza Quechua Narrative », in Kay Sammons and Joel Sherzer (eds.), Translating Native Latin American verbal art, Smithsonian Press, Washington (DC), p. 233-251.

OrTEga y Gasset José

1959, « The difficulty of reading », Diogenes, 28, p. 1-17.

Peterson Leighton C. and Anthony K. Webster

2013, « Speech play and language ideologies in Navajo terminology development », Pragmatics, 23 (1), p. 93-116. 
PORT Robert and Adam LEARY

2005, « Against formal phonology », Language, 81 (4), p. 927-964.

REICHARD Gladys

1944, Prayer: the compulsive word, University of Washington Press (American Ethnological Society Monograph, 7), Seattle.

1951, Navaho grammar, J.J. Augustin Publisher, New York.

Rushforth Scott and James Chisholm

1991, Cultural persistence, University of Arizona Press, Tucson.

Sammons Kay and Joel Sherzer (eds.)

2000, Translating Native Latin American verbal art, Smithsonian Press, Washington (DC).

SAMUELS David

2001, « Indeterminacy and history in Britton Goode's Western Apache placenames », American Ethnologist, 28 (2), p. 277-302.

2004, « Language, meaning, modernity, and doowop », Semiotica, 149 (1/4), p. 297-323.

SAMuels David and Thomas Porcello

2015, « Language », in David Novak and Matt Sakakeeny (eds.), Keywords in sound, Duke University Press, Durham, p. 87-98.

SAPIR Edward

1921, Language, Harcourt, Brace, New York.

SEveri Carlo and William Hanks (eds.)

2015, Translating worlds: the epistemological space of translation, Hau Books, Chicago.

Silversmith Shondiin

2015, « VP Jim: above all else, I am a poet », Navajo Times [on-line], April 9 2015, http:// navajotimes.com/ae/arts-ae/vp-jim-above-all-else-i-am-a-poet/\#.VoQkVi57U7w, accessed 07 June 2016.

Silverstein Michael

2003, « Translation, transduction, transformation: skating glossando on thin semiotic ice », in Paula Rubel and Abraham Rosman (eds.), Translating cultures, Berg, New York, p. 75-105.

SHERZER Joel

1987, « A discourse-centered approach to language and culture », American Anthropologist, 89, p. 295-309.

1994, « The Kuna and Columbus: encounters and confrontations of discourse », American Anthropologist, 96, p. 902-924.

ToHE Laura

2005, Tséyi': deep in the rock, University of Arizona Press, Tucson.

WALDROP Rosmarie

2009, «Translating the sound in poetry: six propositions », in Marjorie Perloff and Craig Dworkin (eds.), Sound of Poetry/Poetry of Sound, University of Chicago Press, Chicago, p. 60-65.

Weidman Amanda

2006, Singing the classical, voicing the modern: the postcolonial politics of music in south India, Duke University Press, Durham. 
2014, «Anthropology and voice », Annual Review of Anthropology, 43, p. 37-51.

2015, « Voice », in David Novak and Matt Sakakeeny (eds.), Keywords in sound, Duke University Press, Durham, p. 232-245.

Webster Anthony K.

2004, Navajo poetry, linguistic ideology, and identity: the case of an emergent literary tradition, Ph.D. dissertation, University of Texas at Austin.

2006, « The mouse that sucked: on "translating" a Navajo poem », Studies in American Indian Literature, 18 (1), p. 37-49.

2009, Explorations in Navajo poetry and poetics, Albuquerque, University of New Mexico Press.

2012, «Who reads Navajo poetry and what are they reading? Exploring the semiotic functions of contemporary written Navajo », Social semiotics, 22 (4), p. 375-408.

2013, " "The validity of Navajo is in its sounds": on Hymes, Navajo poetry, punning, and the recognition of voice $»$, Journal of folklore research, 50 (1-3), p. 117-144.

2015a, Intimate grammars: an ethnography of Navajo poetry, University of Arizona Press, Tucson.

2015b, «"Everything got kinda strange after a while": some reflections on translating Navajo poetry that should not be translated », Anthropology \& Humanism, 40 (1), p. 72-93.

$2015 \mathrm{c}$, « The poetry of sound and the sound of poetry: Navajo poetry, phonological iconicity, and linguistic relativity », Semiotica, 207, p. 279-301.

2017, " "So it's got three meanings dil dil." Seductive ideophony and the sounds of Navajo poetry », Canadian Journal of Linguistics, forthcoming.

nd, « "I don't write Navajo poetry, I just speak the poetry in Navajo": ethical listeners, poetic communion, and the imagined future publics of Navajo poetry ", in Paul Kroskrity and Barbra Meek (eds), Engaging Native American Publics, Routledge, New York.

WeRITO Vincent

2014, « Understanding Hózhó to achieve critical consciousness: a contemporary Diné interpretation of the philosophical principles of Hózhó»», in Lloyd Lee (ed.), Diné perspectives: revitalizing and reclaiming Navajo thought, University of Arizona Press, Tucson, p. 25-38.

WERnER Oswald

1994, « Ethnography and translation: issues and challenges », Sartoniana, 7, p. 59-135. WoodBury Anthony

2007, « On thick translation in linguistic documentation », Language Documentation And Description, 4 (Peter K. Austin [ed.]), p. 120-135.

WOOLARD Kathryn

1998, « Simultaneity and bivalency as strategies in bilingualism », Journal of Linguistic Anthropology, 8 (1), p. 3-29.

Young Robert and William Morgan

1987, The Navajo language, University of New Mexico Press, Albuquerque.

Young Robert and William Morgan with the assistance of Sally MidgetTe 1992, Analytical lexicon of Navajo, University of New Mexico Press, Albuquerque. 
